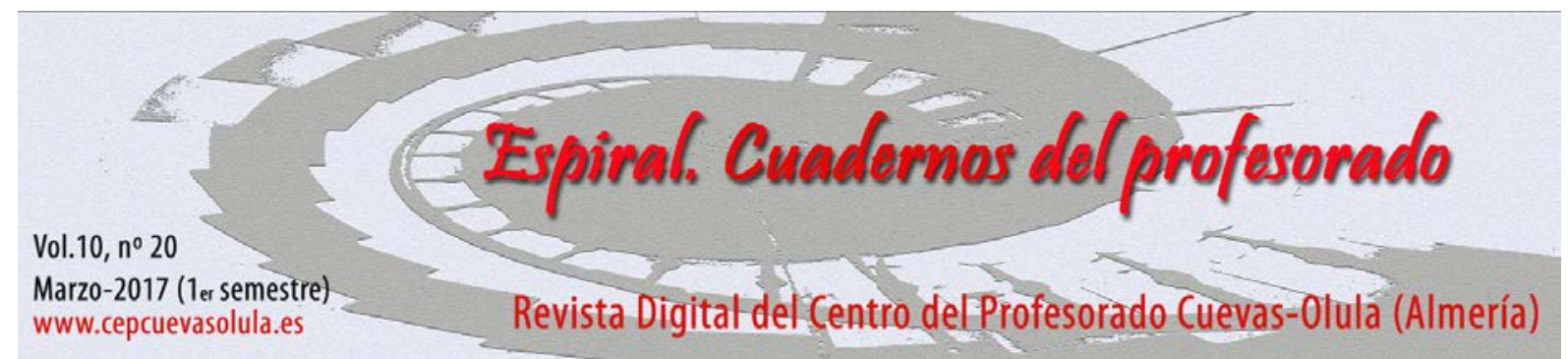

\title{
The role of management administration to implement key competences in
}

\author{
schools: a case study
}

\section{El rol de la gestión directiva para implementar las competencias clave en las escuelas: un estudio de caso}

\author{
David Hortigüela Alcalá ${ }^{(1)}$, Ángel Pérez-Pueyo ${ }^{(2)}$ and Javier Fernández-Río ${ }^{(3)}$ \\ ${ }^{(1)}$ University of Burgos, Spain \\ (2) University of León, Spain \\ ${ }^{(3)}$ University of Oviedo, Spain
}

\begin{abstract}
The goal of this research was to assess the impact of management administration to implement key competencies in schools. All management teams of the 30 existing secondary schools in the city of Burgos agreed to participate. An experimental pre-test, post-test design and a mixed data extraction procedure, quantitative-qualitative, were used. Two groups were generated at random: A, experimental (16 schools) and B, control (14 schools). In the first one, key competencies were implemented under the supervision of the schools' management administration along the school year (deductive), while in schools in group B the implementation process was conducted by the teachers (inductive). Quantitative data was obtained through the key Competencies Implementation Questionnaire, while discussion groups were used for qualitative data collection. Quantitative results showed that the deductive procedure had a significant positive impact in the schools' identity and administration, and in the methodological and assessment strategies used by the teachers. Qualitative results reflected three themes: improve school coordination, teacher and training innovation, and student learning. It can be concluded that direct supervision from the school administrators seems to be necessary to successfully implement key competencies.
\end{abstract}

Key words: key competences, management teams, continuing education teachers, methodology, student learning.

RESUMEN: El objetivo de esta investigación fue analizar los efectos de un trabajo de secuenciación de las competencias clave (CCC) por los equipos directivos en: 1) la importancia para la gestión del centro, 2) la formación permanente del docente, 3) las estrategias metodológicas y evaluativas, y 4) el aprendizaje del alumnado. Todos los equipos directivos de los 30 Institutos de Educación Secundaria existentes en la ciudad de Burgos accedieron a participar. Se empleó un diseño experimental pretest-postest con grupos naturales y un procedimiento de extracción de datos mixto, cuantitativo-cualitativo. Se generaron dos grupos al azar, el A, experimental, con 16 centros, y el B, control, con 14. En el primero se llevó a cabo un trabajo de secuenciación de las CCC a lo largo de un curso escolar. El instrumento utilizado en la parte cuantitativa fue el cuestionario validado de implantación de las CCC, mientras que en la cualitativa fue un grupo de discusión con los integrantes de uno de los equipos directivos participantes. Los resultados reflejan cómo en el grupo A se encontraron mejoras significativas en la importancia de la secuenciación de las CCC para la gestión del centro y en las estrategias metodológicas y evaluativas. En este grupo, los miembros directivos más formados valoraron cómo más útil esta forma de trabajo a nivel profesional, mientras que en el B los más jóvenes mostraron una mayor valoración. El grupo de discusión valoró satisfactoriamente la intervención. Se concluye la bondad de vincular el tratamiento de elementos curriculares como las CCC a las funciones directivas de manera secuenciada para mejorar los procesos educativos.

Palabras clave: competencias clave, equipos directivos, formación permanente profesorado, metodología, aprendizaje alumno. 
Hortigüela Alcalá, D., Pérez-Pueyo, A., \& Fernández-Río, J. (2017). The role of management administration to implement key competences in schools: a case study. Espiral. Cuadernos del Profesorado, 10(20), 3-13. Available: http://espiral.cepcuevasolula.es/

Received: 13/11/2016

Accepted: 14/02/2017
Correspondence to:

dhortiguela@ubu.es

\section{Introduction}

Many educational changes have occurred in recent years and some voices suggest that schools' executive teams should be leaders of those changes ( $\mathrm{Li}, 2015)$. However, there are several barriers which must be overcome to conduct processes that can modify academic and/or management structures (Wierenga, Kamsteeg, Simons, \& Veenswijk 2015). In a changing world, education and society must go by hand in the promotion of learning that will allow students to autonomously adapt to different contexts (Wood, 2016). Management teams must overcome resistances found both in academic functioning and teacher training. Almost twenty years ago, the European Higher Education Association incorporated the concept of competence into the university education system and both the European Parliament and the European Council (European Commission, 2004) aimed the different countries to establish a common European framework in education to ensure that all citizens of the European Union are trained to be competent in different areas, and thereby contribute to the evolution of society politically, economically and socially. State members were also urged, through its educational policies, to implement these recommendations. In Spain, European convergence began with the Organic Law of Education (2006) and the emergence of basic competences, that did not exactly match those defined as Key Competences by Europe. In 2013, the Organic Law for the Improvement of Educational Quality (2013) re-named them key competences, reducing to seven the eight initially defined in Europe: 1) competition in linguistic communication, 2) mathematical competence and basic science and technology, 3) digital competence, 4) social and civic competences; 5) learning to learn, 6) awareness and cultural expressions and 7) sense of initiative and entrepreneurship.

Since 2006, the key competences had become the most significant curricular element in compulsory education (Yuayai, Chansirisira, \& Numnaphol., 2015; Méndez-Alonso, MéndezGiménez, \& Fernández-Río, 2015). However, the way they should be implemented in schools is not clear, since there are no protocols defined by law. Two procedures are commonly used: (1) Inductive, more widespread, it allows the different curricular areas to implement the key competences the way they understand it should be done, which causes the absence of guidelines and agreements to regulate the implementation (Polo, 2010) and (2) Deductive, less widespread, the schools' management teams supervise the implementation process, which involves more work for them, but allows for a more homogeneous impact (Zabala \& Arnau, 2007). Researchers believe that only through long term and supervised implementation protocols, which can show the strength and consistency of the key competences approach, there will be a chance to substantiate educational improvements via with competence work (De-Juanas, Martín, \& Pesquero, 2016). The role of responsible managers clearly influences the schools' dynamics (Prichard \& Moore, 2016) and they should be involved to promote educational changes like key competences. Attitude, motivation and involvement are the best indicators of how professionals give real answers to educational phenomena (Emo, 2015). However, most experiences end up in mere intentions. There is a need to assess the work performed by schools administrators to make innovations fit the existing structures (Bird, Dunaway, Hancock \& Wang, 2013), and some authors recommend the use of mixed methods: quantitative before and after the intervention and qualitative to assess the process in detail (Schram, 2014).

Based on the aforementioned, the goal of this research was to assess the impact of management administration to implement key competencies in schools. The objectives were: a) to 
analyze the effects of the use of a deductive procedure in the school administration, in the continuing teacher training, in the methodological and assessment strategies used by the teachers and on student learning; b) to assess the incidence of age, experience in school administration and academic training in the implementation process; and c) to assess the perceptions of the management teams on the changes produced by the intervention.

\section{Material y Methods}

\section{Participants}

30 management teams of all the secondary schools in the city of Burgos (Spain) agreed to participate (the entire population sample). 17 were charter schools, 12 public schools and 1 private school. The questionnaire was completed by the principal or the head teacher of each school. The average age of the management teams was $50.31 \pm 17.13$ years, and their experience in school administration was $6.71 \pm 4.52$ years. Two directors had a Ph.D., four a M.S. and/or more than one university degree, and the remaining 24 one university degree. All participating schools were randomly distributed into an experimental group $(A=16$ schools) and a control group $(B=14$ schools). The experimental group conducted a deductive process to implement the sequencing of key competencies along the school year.

\section{Instruments}

\section{Quantitative}

The Key Competences Implementation Questionnaire (KCIQ; Hortigüela et al., 2014) was used. It includes 28 items, grouped in four subscales, which assess the relevance of the key competences for: (1) school identity and administration, (2) Continuing teacher training, 3) Methodological and assessment strategies, 4) students' learning. Participants responded in a 1-5 likert scale. High reliability composite (.91), and adequate Extracted Media Variance (51.67\%), Cronbach's alpha (.820) and McDonald's Omega reliability (.68) were obtained. A 95\% interval confidence was used. Exploratory Factor Analysis revealed the four-factor solution with a self-value greater than one. These two factors explained the total variance, once corrected and rotated the components matrix (Varimax Normalized). The auto initial value for the first factor corresponded to $22.328 \%$ of the variance, $20.211 \%$ to the second, $18.392 \%$ to the third and $16.281 \%$ to the fourth. To check the adequacy of the questionnaire to the sample used (goodness of fit) a Confirmatory Factor Analysis Principal Components was conducted. Appropriate index KMO (Kaiser-Meyer-Olkin) values were obtained (.812) in the Bartlett sphericity test $(p<.05)$, which presented a Chi-square value of 139.142 and 13 degrees of range. Indices obtained from the covariance matrix showed satisfactory adjustments for the RMSEA (Root Mean Square Error approximation) $=.071$ (values up to .08 represent reasonable approximation errors; Smith, 2010). In the CFI (Comparative Fit Index) and GFI (Goodness of Fit Index) values of 0.89 and 0.921 respectively indicated a good fit (Hu \& Bentler, 1999).

\section{Qualitative}

Qualitative information from the study was obtained from a discussion group created within the experimental group. The goal was to assess the perceptions of a group of participants on the changes produced by the intervention program. It was intended to deepen in the experience, contrasting ideas (Patton, 2002). To achieve these goals a group of questions were selected (Table 1). The discussion was semi-structured, favouring the conversation to create an experiential, critical and reflective approach (Simpson, 2016). This allowed researchers to dig deeper into the intervention process, obtaining a greater volume of data on how participants experienced the deductive process of sequencing the implementation of the key competences along the school year. The discussion focused on three topics: 1-"Improved academic coordination", 2-"Teacher training and innovation" and 3"Student Learning" (two questions for each). These three categories were used to structure the 
presentation of the qualitative data obtained. It lasted 90 minutes (approximately) and it was recorded on video for a proper transcription.

\section{Table 1}

Basic script of the questions used in the discussion group.

1. Did the deductive process promote more academic coordination? How?

2. To what extent sequencing the key competences within the different courses means greater educational coherence?

3. Do Implementing key competences require further teacher training? How was it managed?

4. Is the implementation of key competences a necessary educational innovation? Why?

5. Can the sequenced work of the key competences influence student learning? How?

6. What steps were established to assess the impact of the key competences on students' learning?

\section{Design and procedure}

An experimental pre-test, post-test design and a mixed data extraction procedure quantitativequalitative were used. Regarding the internal validity of the design, all schools of the city of Burgos participated. Regarding the external validity (replicability) of the experience in other educational contexts, it is guaranteed because the implementation of key competences is mandatory by law in Spain. The whole research project was conducted along the 2015-16 school year.

The management teams belonging to the experimental group were trained in a 30-hour seminar on theory and practice of the important curricular role played by the key competences and how to implement and to sequence them in the different grades/courses and curricular areas/subjects. A precise plan was designed to decide which element of each key competence had to be included on each area and on each grade, including assessment procedures. This plan had to be conducted and supervised by the management teams of each school: deductive approach. In the control group, management teams attended a 30-hour seminar on theory and practice of the important curricular role played by the key competencies and how to implement them, but a plan to implement and sequence them was not designed. Therefore, each curricular area/subject was in charge of the implementation and sequencing of the key competences: inductive approach. The research team, with more than 10 years of experience on key competences, conducted both seminars.

To conduct the research project permission from the Ethics Committee of the University of the Principal Investigator, as well as from the educational centres contacted was obtained. All management teams signed a written consent to be part of the study. Anonymity was guaranteed along the whole process.

\section{Data Analisys}

\section{Quantitative}

All data obtained from the questionnaire was analyzed using SPSS 22.0 (IBM, Chicago, IL, USA)). First, exploratory analyses were conducted to establish whether data met parametric assumptions. The Kolmogorov-Smirnov test $(\mathrm{n}>50)$ showed that all variables were normally distributed. Therefore, parametric tests were used to analyze gathered data. Finally, a two-way mixed ANOVA was used for independent group analysis.

\section{Qualitative}

The computer program WEFT QDA was used in data management. All data extracted from the discussion group was analyzed using thematic content analysis (Libarkin \& Kurdziel, 2002) and constant comparison (Denzin and Lincoln, 1994). The content analysis focused on finding patterns in the text and coding extracts matching with crossed patterns (Saldaña, 2009). The issues that appeared in the first independent analysis were critically examined by all researchers through a thoughtful dialogue. Reliability was supported through continuous feedback and participatory analysis by researchers, who reviewed the emerging categories, to make the final results reliable, credible and transferable (Lincoln \& Guba, 1985). The analysis procedures that have been used are restricted to proposals of fragmentation and articulation based in the Grounded Theory (Strauss \& Corbin, 2002). 
Each meaningful extract was linked with one of the defined categories. The goal was to use the information obtained to give the study greater comprehensibility through the transfer of the results. The final categories that emerged are presented in the results section with the support of several examples of texts (Cohn, 1991).

Table 2

Pre-test-post-test comparisons

\begin{tabular}{|c|c|c|c|c|c|c|c|}
\hline & \multicolumn{3}{|c|}{ PRE-TEST } & \multicolumn{4}{|c|}{ POST-TEST } \\
\hline & $M$ & $S D$ & Var. & $M$ & $S D$ & Var. & $f$ \\
\hline \multicolumn{8}{|c|}{ Experimental Group (A) } \\
\hline F.1. School identity and administration & 3.34 & .25 & .06 & $4.43^{* a}$ & .18 & .03 & .93 \\
\hline F.2. Continuing teacher training & 3.39 & .19 & .03 & 3.96 & .24 & .05 & - \\
\hline F.3. Methodological and assessment strategies & 3.12 & .31 & .09 & $4.38^{* * a}$ & .22 & .04 & .92 \\
\hline F.4. Students' learning & 3.31 & .22 & .04 & 3.89 & .25 & .06 & - \\
\hline \multicolumn{8}{|c|}{ Control group (B) } \\
\hline F.1. School identity and administration & 3.20 & .33 & .11 & $3.31^{\mathrm{b}}$ & .29 & .08 & - \\
\hline F.2. Continuing teacher training & 3.41 & .42 & .17 & 3.38 & .36 & .12 & - \\
\hline F.3. Methodological and assessment strategies & 3.24 & .37 & .13 & $3.35^{\mathrm{b}}$ & .42 & .17 & - \\
\hline F.4. Students' learning & 3.21 & .21 & .04 & 3.24 & .26 & .06 & - \\
\hline
\end{tabular}

Note: different superscripts indicate significant differences between groups at $\mathrm{p}<.005 ; \mathrm{f}$ : effect size; *Pre-post differences factor 1 (group A); **Pre-post differences in factor 3 (group A).

\section{Results}

\section{Pre-Test-Post-Test Comparisons}

Two Anova analysis with repeated measures mixed way for independent groups were conducted (Table 2). It showed how factor 1: "Relevant for school management" and factor 3: "methodological and assessment strategies" obtained significant differences in both the pre-test-posttest and in the post-test between groups. This reflects the impact that the intervention process had in the experimental group. The effect sizes were: .93 and .92 respectively, which can be considered large (Cohen, 1988).

\section{Inferential Analysis: ANOVAS}

Regarding the Anova analysis and considering the differences pre-test-post-test in the four study factors in the two groups, a variable called: "usefulness of key competences in school management" was generated. This variable reflected the change experienced by the participants, and it was used as the dependent variable in this analysis. This required conducting a one-way Anova Bonferroni of the independent groups to check whether there were statistically significant differences between both study groups at post-test. The influence of other three independent variable on this new dependent variable was also assessed: (1) Age: it was categorized into: 1-"30-45 years", 2-"46-60 years", and 3-"more than 60 years", (2) years of experience in management: it was categorized into: 1"less than 3 years ", 2-"3-5 years", 3-"6-8 years", and 4-"more than 8 years"; and (3) academic training: it was categorized into: 1-"One academic degree", 2-"Master and/or more than one academic degree", and 3-"Ph.D.". A post hoc was conducted to find significant difference between groups (Table 3). 
Table 3

Usefulness of key competences in school management.

\begin{tabular}{|c|c|c|c|}
\hline & $\mathbf{F}$ & gl & $p$ \\
\hline \multicolumn{4}{|l|}{ Experimental Group (A) } \\
\hline Age & 102.45 & 2 & .152 \\
\hline Years of experience in management & 94.514 & 1 & .241 \\
\hline Academic training & 89.41 & 3 & $.022 *$ \\
\hline \multicolumn{4}{|l|}{ Control Group (B) } \\
\hline Age & 97.341 & 2 & $.034 * *$ \\
\hline Years of experience in management & 84.398 & 1 & .282 \\
\hline Academic training & 93.398 & 2 & .195 \\
\hline
\end{tabular}

$* p<.05$ between "one academic degree" (mean: 4.02) and "Doctorate degree" (mean: 4.72)

** $p<.05$ between "over 60" (mean: 4.05) and "between 30 and 45" (mean: 4.75)

In the experimental group significant differences were found in "academic training" in the members with a Ph.D. $(\mathrm{F}(16)=102.45, \mathrm{p}=.022)$. In the control group significant differences were obtained in “age” in the members' 30-45 years old: $(F(14)=97,341, p=.034)$.

\section{Qualitative Analysis}

From all the information obtained in the discussion group three issues or fundamental categories emerged: 1) Improve school coordination, 2) Teacher and training innovation, and 3) Student learning. Categories are discussed below (the number of extracts are also included) and quotes are used to exemplify them.

Improve school coordination (275 meaningful extracts). The managerial teams that experienced a deductive approach to the implementation of the key competences experienced a progressive and positive change in the coordinated work among teachers, although not without difficulties throughout the process:

"At first it took a while to decide with the curricular areas which items of each competence will each one work, but after a few meetings with the teachers we begin to see consistency in the process"

The management teams believed that working in groups the participating teachers were able to set common procedures:

"We are proud that we [management team] were able to generate changes, which will hopefully consolidate in the future"

"We think that it is very positive that teachers from different areas who had never worked together realize that there are common aspects to do, such as assessment, oral presentations..."

"The assessment and contribution to the each student's skills is clear now, and also that all areas contribute, not only one"

Teacher training and innovation (283 meaningful extracts). Members of the management teams believed that it was essential to train teachers to carry these coordination processes:

"We took a step forward because we believe that the key competences are more than just a fashion [...]. It is a coherent process that gives unity to school”

"Teacher's motivation and training is essential to address these processes. Some teachers, at first, say no to anything involving minimal change” 
Members of the management team also commented that innovation processes must have continuity to generate changes:

"We are pleased with the results of this experience; however we are aware that we must continue to work like this or the results will disappear"

"It's not easy to convince teachers to become involved in these processes, as it entails more work, without financial recognition or reduction of hours"

"Our main problem, being a public institution, is that when we make changes through projects, many teachers move to another school [...]. We strive to ensure that the changes remain no matter who comes to teach"

Student learning (291 meaningful extracts). Members of the management teams were cautious when dealing with the possible impact of the key competences in students' learning. They acknowledged that the deductive process lead to a coherent planning of work in the different areas and courses, which helped students be more involved and organize better their tasks:

"It is true that students appreciated that the teachers' demands (tasks, oral presentations and assessment procedures) were similar between subjects, allowing them to better organize their work and study"

Managerial teams also believed that it would be interesting to work together with other schools involved in these processes:

\begin{abstract}
"Contrasting experiences with other schools would be truly enriching"
"It is important to see the difficulties that others have had and seek common guidelines [...]. Each school has a specific context, but that this issue [key competences] is global and we all must row in the same direction."
\end{abstract}

\title{
Discussion
}

The goal of this research was to assess the impact of management administration to implement key competencies in schools. The objectives were: a) to analyze the effects of the use of a deductive procedure in the school administration, in the continuing teacher training, in the methodological and assessment strategies used by the teachers and on student learning; b) to assess the incidence of age, experience in school administration and academic training in the implementation process; and c) to assess the perceptions of the management teams on the changes produced by the intervention. Quantitative results showed that the deductive procedure had a significant positive impact in the schools' identity and administration, and in the methodological and assessment strategies used by the teachers. Qualitative results reflected three themes: improve school coordination, teacher and training innovation, and student learning.

The first objective was to analyze the effects of the use of a deductive procedure in the school administration, in the continuing teacher training, in the methodological and assessment strategies used by the teachers and on student learning. Results showed that only the management teams that used a deductive procedure to implement the key competences significantly increased the schools' identity and administration, as well as the teachers' methodological and assessment procedures. These results reflect how important is to generate innovation in education to involve management teams in the process (Truijen, Sleegers, Meelissen, \& Nieuwenhuis, 2013). Ansar (2015) indicated that educational changes can only have a real impact in schools when the leader role is performed by the administrators in deductive processes. One of the biggest advantages of this framework is the coordination of teachers in the short term, something that promotes the involvement of the educational community to transform a phenomenon (Mausethagen, 2013). It also fosters the search for common lines of action through cycles of action research. Regarding the positive effect of the deductive process on the teachers' methodological and assessment strategies, educational changes must have a real impact on what teacher do in their classes to be truly effective (Bielta, 2016). School work based on 
the key competences must coordinate strategies between teachers to generate knowledge that students can transfer to their everyday life (Hortigüela et al, 2016). The present research also reflects the important role that assessment plays in a competence-based curriculum. López-Pastor y Palacios (2012) indicated that assessment should be more than just giving a specific grade/number, because this grade/number is not always associated with learning. Assessment should be associated to student feedback to improve teaching. Previous research has showed how students valued more positively formative processes and shared evaluation systems than traditional assessment (Hortigüela, PérezPueyo, \& Salicetti, 2015). In the control group, no significant improvements were observed in any of the four factors, reflecting that progress is difficult in schools where there is no coordination from the management teams.

The second research objective was "to assess the incidence of age, experience in school administration and academic training in the implementation process". Results showed that in the experimental group management teams with more training (Ph.D.) perceived more useful for the school administration the implementation of key competences. Possessing a doctoral degree and being knowledge on research could be the leading forces to promote processes of change in schools. Previous research has showed that teachers with less training were more reluctant to changes and new learning experiences (Thornburg \& Mungai, 2011). In the control group, younger management teams were more positive to implement the key competences. Probably, younger administrators have learned more about them in their initial training. However, previous studies have showed that age does not become influential when teachers want to work in schools where the key competences are an important element (Pepper, 2011).

The third research objective was "to assess the perceptions of the management teams on the changes produced by the intervention". Three categories or themes emerged from data analysis. The first one, "improve school coordination" reflects that the deductive process used to sequence the implementation of the key competences improved the coordination among teachers in the school. However, many administrators acknowledged that it was not easy to find. Laferrière, Law \& Montané (2012) pointed out that the fact that the whole community does not want to make changes should not be a limiting factor, because if the outcomes are good processes they will be internalized and the number of participants in the change will increase. The second theme/category was "teacher training and innovation". Participants highlighted how important is to train teachers in the school, because there are no plans or protocols set by the national administration. Deductive procedures like the one used in this study helped the schools' administrators train their teachers to integrate an educational innovation like the key competences. Regarding the third theme/category, "student learning", the management teams were cautious because it was difficult to assess the impact of a new approach like the key competences in only one school year. However, they felt that the deductive process used to sequence the implementation of the key competences had led to a coherent planning of the work in the different areas and courses, which helped students become more involved and organized.

\section{Conclusions}

The use of a deductive process to implement the sequencing of the key competences in secondary education had a significant positive impact in the schools' identity and administration, and in the methodological and assessment strategies used by the teachers. Results also showed that the deductive process helped improve the school's coordination, promoted teacher and training innovation, and probably helped student learning.

The present study also holds some limitations. First, participating management teams belong to schools located in a single city. Future research should expand the targeted population to see if similar results can be obtained in different schools located in other cities and / or autonomous regions. Secondly, the research was conducted only in secondary education. Future research should be conducted in primary education. 


\section{References}

Ansar, R. (2015). Measuring the Performance of School Superintendent. Journal of Education and Practice, 6(2), 103-108.

Balaguer, I., Guivernau, M., Duda, J. L. y Crespo, M. (1997). Análisis de la validez de constructo y de la validez predictiva del cuestionario de clima motivacional percibido en el deporte (PMCSQ-2) con tenistas españoles de competición. Revista de Psicología del Deporte, 11, 41- 58.

Biesta, G. (2016). Improving Education through Research? From Effectiveness, Causality and Technology to Purpose, Complexity and Culture. Policy Futures in Education, 14(2), 194-210. doi: $10.1177 / 1478210315613900$.

Bird, J., Dunaway, D., Hancock, D. y Wang, C. (2013). The Superintendent's Leadership Role in School Improvement: Relationships between Authenticity and Best Practices. Leadership and Policy in Schools, 12(1), 37-59. doi: 10.1080/15700763.2013.766348.

Cohen, J. (1988). Statistical power analysis for the behavioral science (2nd ed.). Hillsdale, NJ: Lawrence Erlbaum Associates.

Cohn, P. J. (1991). An exploratory study on peak performance in golf. The Sport Psychologist, 5, 1-14.

Consejo de la Unión Europea (2000). Informe del Consejo Europeo de Lisboa. Conclusiones Presidenciales. [5680/91 EDU 18]. Recuperado de http://www.europarl.europa.eu/summits/lis1_es.htm

Consejo de la Unión Europea (2001). Informe del Consejo "Educación” al Consejo Europeo sobre los "futuros objetivos precisos de los sistemas de educación y formación” [5680/91 EDU 18]. Recuperado de http://ec.europa.eu/education/policies/2010/doc/rep_fut_obj_es.pdf

Consejo de la Unión Europea (2002). Informe del Consejo Europeo de Barcelona. Conclusiones Presidenciales. [SN 100/2/02 REV 2]. http://www.consilium.europa.eu/ueDocs/cms_Data/docs/pressData/es/ec/70829.pdf

Consejo de la Unión Europea (2002). Programa de trabajo detallado para el seguimiento de los objetivos concretos de los sistemas de educación y formación de Europa. [2002/C 142/01]. En Diario Oficial de las Comunidades $\quad$ Europeas. Recuperado http://eurlex.europa.eu/LexUriServ/LexUriServ.do?uri=OJ:C:2002:142:0001:0022:ES:PDF

European Commission (2004). Implementation of “Education and Training 2010" work programme. Working group on Key Competences foor Lifelong Learning. A European Reference Framework. Progress Report November 2004. Recuperado de http://ec.europa.eu/education/policies/2010/doc/basicframe.pdf

Parlamento Europeo (2006). Recomendación del Parlamento Europeo y del Consejo de 18 de Diciembre de 2006 sobre competencias clave para el aprendizaje permanente (2006/962/CE). En Diario Oficial de la Unión Europea. Recuperado de http://eurlex.europa.eu/LexUriServ/LexUriServ.do?uri=OJ:L:2006:394:0010:0018:ES:PDF

Corbetta, P. (2007). Metodologías y técnicas de investigación social. Madrid: McGrawHill.

De-Juanas, A., Martín, R., y Pesquero, E. (2016). Teaching Competences Necessary for Developing Key Competences of Primary Education Students in Spain: Teacher Assessments. Teacher Development, 20(1), 123-145. doi: 10-4438/1988-592X-RE-2011-360-115.

Denzin, N. K., y Lincoln, Y. S. (1994). Handbook of Qualitative Research. Thousand Oaks, CA: Sage.

Díez-Hernando, C. (2008). La Competencia Social y Ciudadana en la LOE. Avances en supervisión educativa: revista de la Asociación de Inspectores de Educación de España, 9, 1-12.

Escamilla, A. (2008). Las Competencias básicas: Claves y Propuestas para su desarrollo en los Centros. Barcelona: Graó.

Emo, W. (2015). Teachers' Motivations for Initiating Innovations. Journal of Educational Change, 16(2), 171195. doi: 10.1007/s10833-015-9243-7.

Gómez-Pimpollo, N., Pérez-Pintado, M. y Arreaza, F. (2007). Programación, desarrollo y evaluación de las Competencias Básicas. Consejería de Educación de la Junta de Castilla La Mancha. Recuperado de http://www.slideshare.net/orientacionliceo/programacin-desarrollo-y-evaluacin-de-las-ccbb

Hall, J., y Ryan, K. (2011). Educational Accountability: A Qualitatively Driven Mixed-Methods Approach. Qualitative Inquiry, 17(1), 105-115. 
Herrero, J. (2010). El análisis factorial confirmatorio en el estudio de la estructura y estabilidad de los instrumentos de evaluación: un ejemplo con el cuestionario de autoestima CA-14. Psychosocial Intervention, 19(3), 289-300.

Hortigüela, D, Pérez-Pueyo. A., y Abella, V. (2014). Estudio sobre el proceso de implantación y seguimiento de las competencias básicas en los centros educativos de educación secundaria de la ciudad de Burgos. Análisis desde la perspectiva de los equipos directivos y de los docentes de educación física. Repositorio institucional de la Universidad de Burgos. Recuperado de http://riubu.ubu.es/handle/10259/3588

Hortigüela, D., Pérez-Pueyo, A., y Abella, V. (2016). ¿Cómo perciben las competencias básicas los docentes? Estudio cualitativo sobre su incorporación como herramienta de aprendizaje. Qualitative Research in Education, 5(1), 25-48. doi:10.17583/qre.2016.1348.

Hortigüela, D., Pérez Pueyo, A. y Salicetti, A. (2015). ¿Cómo percibe el alumnado universitario de educación física la evaluación recibida? Contraste de dos metodologías diferentes. Retos. Nuevas tendencias en Educación Física, Deporte y Recreación, 28, 66-70.

Hu, L., y Bentler, P. (1999). Cutoff criteria for fit indexes in covariance structure analysis: Conventional criteria versus new alternatives. Structural Equation Modeling, 6(1), 155. http://dx.doi.org/10.1080/10705519909540118

Laferrière, T., Law, N., y Montané, M. (2012). An International Knowledge Building Network for Sustainable Curriculum and Pedagogical Innovation. International Education Studies, 5(3), 148-160.

Ley Orgánica 2/2006, de 3 de mayo, de Educación (BOE, 4 de Mayo).

Ley Orgánica 8/2013, de 9 de diciembre, para la mejora de la calidad educativa (BOE, 10 de Diciembre).

Li, Y.L. (2015). The Culture of Teacher Leadership: A Survey of Teachers' Views in Hong Kong Early Childhood Settings. Early Childhood Education Journal, 43(5), 433-445. doi: 10.1007/s10643-0140674-1.

Libarkin, J. C., y Kurdziel. J. P. (202). Research methodologies in science education: Qualitative data. Journal of Geoscience Education, 50, 195-200.

Lincoln, Y. S., y Guba, E. (1985). Naturalistic inquiry. Newbury Park, CA: Sage.

López-Pastor, V. y Palacios, A. (2012). Percepción de los futuros docentes sobre los sistemas de evaluación de sus aprendizajes. Education in the knowledge society, 13(3), 317-341.

Mausethagen, S. (2013). A Research Review of the Impact of Accountability Policies on Teachers' Workplace Relations. Educational Research Review, 9, 16-33. doi:10.1016/j.edurev.2012.12.001

Moya, J. y Luengo, F. (coords.). (2009). Las competencias básicas en la práctica. Madrid: Proyecto Atlántida.

Patton, M. Q. (2002). Qualitative Research and Evaluation Methods. Thousand Oaks, CA: Sage.

Pepper, D. (2011). Assessing Key Competences across the Curriculum--And Europe. European Journal of Education, 46(3), 335-353. http://dx.doi.org/10.1111/j.1465-3435.2011.01484.x

Pérez-Pueyo, A. (Coord.) (2013). Programar y evaluar competencias básicas en 15 pasos. Barcelona: Graó.

Polo, I. (2010). La evaluación de las competencias básicas. Avances en Supervisión Educativa. Revista de la Asociación de Inspectores de Educación en España. $N^{o} 12$, mayo. Recuperado de http://www.adide.org/revista/index.php?option=com_contentytask=viewyid=339yItemid=68

Prichard, C., y Moore, J.E. (2016). Variables Influencing Teacher Autonomy, Administrative Coordination, and Collaboration. Journal of Educational Administration, 54(1), 58-74. doi: http://dx.doi.org/10.1108/JEA-09-2014-0113.

Saldaña, J. (2009). The Coding Manual for Qualitative Researchers. Thousand Oaks, CA: Sage.

Schram, A. (2014). A Mixed Methods Content Analysis of the Research Literature in Science Education. International Journal of Science Education, 36(15), 2619-2638. doi: 10.1080/09500693.2014.908328.

Simpson, A. (2016). Dialogic Teaching in the Initial Teacher Education Classroom: "Everyone's Voice Will Be Heard". Research Papers in Education, 31(1), 89-106. doi: 10.1080/02671522.2016.1106697.

Strauss, A., y Corbin, J. (2002). Bases de la investigación cualitativa: técnicas y procedimientos para desarrollar la teoría fundamentada. Universidad de Antioquia: Colombia.

Truijen, K., Sleegers, P., Meelissen, M y Nieuwenhuis, A. (2013). What Makes Teacher Teams in a Vocational Education Context Effective?: A Qualitative Study of Managers' View on Team Working. Journal of Workplace Learning, 25(1), 58-73. http://dx.doi.org/10.1108/13665621311288485. 
Thornburg, D. y Mungai, A. (2011). Teacher Empowerment and School Reform. Journal of Ethnographic y Qualitative Research, 5(4), 205-217.

Yuayai, R., Chansirisira, P., y Numnaphol, K. (2015). Developing Competency of Teachers in Basic Education Schools. Educational Research and Reviews, 10(12), 1758-1765. doi: 10.5897/ERR2015.2194.

Vázquez, P. y Ortega, J. L. (2011). Competencias Básicas: desarrollo y evaluación en educación Secundaria obligatoria. Valencia: WoltersKluwer.

Wierenga, S. J., Kamsteeg, F. H., Simons, P., y Veenswijk, M. (2015). Teachers Making Sense of ResultOriented Teams: A Cognitive Anthropological Approach to Educational Change. Journal of Educational Change, 16(1), 53-78. doi: 10.1007/s10833-014-9240-2.

Wood, M. B. (2016). Rituals and Right Answers: Barriers and Supports to Autonomous Activity. Educational Studies in Mathematics, 91(3), 327-348. doi: 10.1007/s10649-015-9653-8.

Zabala, A. y Arnau, L. (2007). 11 ideas clave. Cómo aprender y enseñar competencias. Barcelona: Graó.

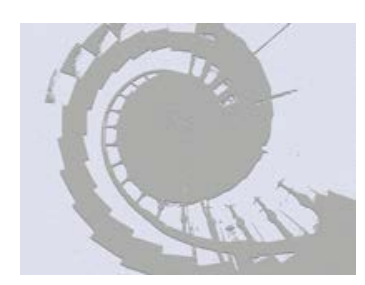

